JURNAL AL BAYAN: JURNAL JURUSAN PENDIDIKAN BAHASA ARAB

p-ISSN 2086-9282 | e-ISSN 2549-1229

\title{
Neology of Arabic in Indonesia
}

\author{
Uki Sukiman \\ Arabic Language and Literature Study Program Universitas Islam Negeri Sunan Kalijaga Yogyakarta, \\ Indonesia
}

\author{
Article History: \\ Received : March 16, 2020 \\ Revised : April 15, 2020 \\ Accepted : May 20, 2020 \\ Published : December 01, 2020
}

Keywords:

Alo Indonesia; New Word; Taulĩd;

Transliteration

*Correspondence Address:

uki.sukiman@uin-suka.ac.id

\begin{abstract}
The development of Arabic which is influenced other language and culture is very interesting to be discussed, because Arabs themselves are not able to give a name to something that does not exist in their nature and their thought, such as naming cases, and terms that come from language and nature of thought of Indonesians. Many of these new words and terms have been featured in one of the Arabic language magazines which is Alo Indonesia. This study aims to find out how the names and terms in Indonesian discourse influenced Arabic and the problems that arise in the process of producing words in the magazine. This research is literature research that used descriptive methods, namely describing the data by concerning to how the use of new Arabic words and terms in Alo Indonesia magazine. The data collection method is done by using the "note-taking" technique which is then collected in the data card. To answer the two main problems above, the writer used Ibrahim Murad's theory of neology. The findings of this study shows that according to five theories by Ibrahim Murad, Alo Indonesia magazine uses more semantic neology theory (at-Taulĩd al-Dalalĩ) and loan neology (alTaulĩd bi al-Iqtirād). The biggest problem in the transliteration process from Indonesian letters into Arabic is that not all vowels and consonants in Indonesian are also available simultaneously in Arabic, and so does the difficulty of finding the equivalent of idea in the expression of these two languages.
\end{abstract}

\section{Introduction}

Language is a communication tool to understand each other. As a means of communicating, language functions as a means of conveying ideas, feelings and desires of human speakers. There is no single human activity apart from the role of language. As part of the cultural element, language is constantly developing and experiencing changes. This change can be caused by the demands of the times or friction with other languages. Thus, a language can influence or be influenced by other languages. For instance, a research that has been conducted by Nikolaos Van Dam, ambassador of the Netherlands to Indonesia (2005-2010) concluded that Bahasa has been influenced by Dutch and 
Arabic. ${ }^{1}$ And So have India and West Africa. Arabic In India is used in eight-part classification: liturgy, teaching and study, nomenclatures, inscriptions, vocabulary assimilation, composition of religio-scholarly text, and marginal utilitarian uses. ${ }^{2}$ Even West African language is written in $\mathrm{Arabic}^{3}$ as well as Malay/Sundanese/Javanese written in Arabic (pegon). In a broader view, Versteegh analyzed the linguistic contacts between Arabic and other languages such as Iran, Central Asia, North India, and parts of Arab Empire that later became separated from this region, for instance Sicily and alAndalus in the West. ${ }^{4}$ Those are examples of the impact of Arabic on other languages. On the contrary, Arabic is also influenced by other language. Wajih Hamad Abderrahman assumend that Arabic is largely indebted to English, the language of modern productive civilization. ${ }^{5}$ This kind of influencing and being influenced in some levels become competition among languages in a society. ${ }^{6}$ Therefore, language is not static but dynamic. Language is called dynamic because it can change according to the context behind it. These changes occur at various levels ranging from phonological, morphological and syntactic, semantic, and lexicon. Among of these levels, the most obvious change is the change in the lexicon ${ }^{7}$. This lexicon level has undergone many developments which are marked by the emergence of words originating from other languages and then accommodated so that they are officially included in the vocabulary of certain languages.

In Arabic, there are several terms to name the foreign vocabulary that influence Arabic, namely al-Muwallad, al-Mu'arrab, and ad-Dakhĩ ${ }^{8}$. The three terms at first glance have almost the same meaning, but some linguists distinguish them by saying that the first term has a more general meaning than the second and third terms. Ibrahim

\footnotetext{
${ }^{1}$ Nikolaos Van Dam, 'Arabic Loanwords in Indonesian Revisited', Bijdragen Tot de Taal-, LandEn Volkenkunde, 166.2/3 (2010): 218-43.

2 Tahera Qutbuddin, 'Arabic in India: A Survey and Classification of Its Uses, Compared with Persian', Journal of the American Oriental Society, 127.3 (2007): 315-38.

${ }^{3}$ John O. Hunwick, 'West Africa and The Arabic Language', Sudanic Africa, 15.2004 (2018): 13344.

4 Kees Versteegh, 'Linguistic Contacts between Arabic and Other Languages', Arabica, 48.4 (2001): 470-508.

${ }^{5}$ Wajih Hamad Abderrahman, 'A Linguistic Study of The Impact of English On Arabic WordFormation', Islamic Studies, 34.2 (2016): 223-31.

${ }^{6}$ Abdel Rahman Yajioui, Developing Language and the Language Development in the Arab World, Arab Center for Research \& Policy Studies, 2012 <http://www.jstor.org/stable/resrep12652>.

7 Abdul Chaer dan Leonie Agustina, Sosiolinguistik Perkenalan Awal (Jakarta: PT Rineka Cipta, 2014), 13.

${ }^{8}$ Muhammad ibn Ibrahĩm al-Hamd, Fiqh Al-Lugah (Saudi Arabiyya: Dār ibn Khizaimah, 2005), 157.
} 
Murād interpreted the first term as a result of the taulĩd (neology) process, namely the production of foreign vocabulary that entered Arabic. In fact, he considered al-Muarrab and al-Dakhil two types of vocabulary resulting from the production process ${ }^{9}$. In The Dictionary English-Arabic, the term of taulid is equated with the meaning of Neology which means ihdaş mufradatin jadidatin (producing new vocabulary) ${ }^{10}$. Likewise in the Oxford dictionary from English into Arabic the term neology means al-Kalimah alMuwalladah or al-Kalimah al-Mustahdasah ${ }^{11}$. Meanwhile, Mohammed Didaoui, referring to the Webster Dictionary, said "A neology is defined as" a new word or a new meaning for established words "and" the use of new words or of new meanings to establish words. Neology is "the novelty of words and phrases" (neology is defined as a new vocabulary or new meaning for existing vocabulary, and is also defined as the use of new vocabulary or the use of new meanings for existing vocabulary ${ }^{12}$.

Every language must have several reasons why it should adopt another language. Considering the development of the Arabic language, several opinions have developed among observers of the language for a long time. It is suspected that muwallad or muwalladah, which means new words in Arabic, initially referred to non-Arabs who were born in an Arabic environment and speak Arabic. Then this word undergoes a shift, so that it refers to a new word and does not come from Arabic because of contact with foreigners. Taking as-Suyūthi's opinion, Muhammad ibn Ibrahim al-Hamd argued that Arabs adopted foreign vocabulary to express discourse that did not exist in Arabic culture or because of admiration of several foreign vocabulary because they were easy to pronounce and deepened their meaning ${ }^{13}$. Meanwhile, Muhammad at-Tūnĩji put forward several other reasons, namely the limitations of the natural environment of the Arabs who did not recognize many names, both plants and animals, also the things that are related to their habitation and building tools because Arabs used to live with a nomadic way.

\footnotetext{
${ }^{9}$ Ibrahim Ibn Murad, Muqaddimah Linazriyah Al- Mu’jam (Beirut: Da.ral-Garb al-Islami, 1997), 134-165.

${ }^{10}$ Research and Study Center, The Dictionary English-Arabi (Beirut: Dār al-Kutub al Ilmiyyah, 2005), 507.

11 Al-Muhĩt M. Badawi, Oxford Studi Dictionary English-Arabic (Beirut: Dar al-Kutub AlIlmiyyah, 2004), 711.

${ }^{12}$ Mohammed Didaoi, Translator as Terminologists (Vienna: Lecture Delivered at the second Seminar on Translation Theory and Alications, 1996), 2.

${ }^{13}$ Muhammad ibn Ibrahĩm al-Hamd, Fiqh Al-Lugah. Mafhūmuh, Mauḍ̄ātuh, Qaḍayāh (Riyad, Dār ibn Khuzaimah, 2005), 165-166.
} 
Furthermore, there are a lot of objects or technology products that are coming from other countries which had them to recognize their real names ${ }^{14}$.

In addition, several scholars mentioned several examples of words that arose as a result of the contact between Arabic and non-Arabic cultures or as a result of the need for Arabs to name new things. Anĩs presented several examples of new language for advertisement. People usually make several new words or the words structure exist in order to advertise their goods. For example, a fresh drink seller uses the name of his shop as جنة الفواكه (paradise for fruits), the barber names his shop as دارالزينة . proposed words to beautify the language in the form of words that have figurative meaning ${ }^{16}$. These expressions have their own meaning and are different from the origin of the words that compose them, for example, استنعجت الذئاب (a weasel in sheep's clothing), ضرب الرقم السياسي (break the record) and others. Meanwhile, Ibrāhĩm Najā in Naşruddĩn mentions that there are many words in Arabic which are affected by the translation of foreign languages into Arabic. For example, اللاضرورة، اللانهاية، اللاشعورية which those words arrangement consisting of negation particles (ل) combined with nouns and preceded by definitive instruments $(\mathrm{J})$, in addition there are words such as كميفية، كمية.

The existence of vocabulary and terms from foreign cultures into Arabic is an interesting phenomenon for Arab researchers themselves or from other countries, including in Indonesia. Naşruddĩn Muhammad in his writing at-taulĩd fi al-Arabiyyah baina ar Rafd wal Qabūl, discusses the causes of its occurrence, the types of taulid, its

14 Muhammad At-Tūnijĩ, Al-Mu'arrab Wa Ad-Dakhil Fi Al-Lugah Al-Arabiyyah Wa Adabihā (Beirut: Dār al-Ma'rifah, 2005), 16-18.

${ }_{15}^{15}$ Ibrāhĩm Anĩs, Dilālatul Alfaz (Cairo: Maktabah al-Anglo al-Mişriyyah, 1958), 58.

${ }^{16}$ Hilmy Khalil, Al-Muwalladu: Dirāsatun fĩ Numuwwin wa Taţawwur al-Lugah Al-'Arabiyyah Ba'dal-Islām (Cairo: al-Haiah al-Mişriyyah al-'āmah Lil-Kitāb,1978), 232.

17 Al-Sayyid Muhammad Nașruddīn, “Al-Muwallad Fil-‘Arabiyyah Baina Ar-Rafụ Wal-Qabūl," Majalah Kulliyatud-Dirāsat al-Islāmiyyah wal- 'Arabiyyah Banāt Damanhūr, 2.3 (April, 2017): 138-264. 
rules, some equivalents that oppose taulĩd, and explains several cases of taulid in words and in phrases. ${ }^{18}$

If the article above still talks about neology in general, the next two writings focus on the case of neology which comes from English and its rules. Ramadan Elmgrab (2011) with his writing entitled Methods of Creating and Introducing New Term in Arabic Contributions from English -Arabic Translation ${ }^{19}$ and Cristina Salimando (2017) with the title Arabic Neologism in IT terminology: The Role of Academic ${ }^{20}$. The first paper speaks of the absence of definite standardization of the existence of new vocabulary from English into Arabic. He concluded that almost all word translations rely on the sounds of the language so that they ignore the aspect of meaning. Therefore, he offers three principles, namely derivation (al-Isytiqāq), Arabization (at-Ta'rĩb) and blending (an-Naht) to solve this problem. The second article concentrated on terminology in the field of Information and Technology. This article talks about the confusion that occurs in the use of one terminology but the translation becomes many without standardization in absorption, for example the word 'cellular phone' can be called silülir, mübail, mahmūl, and Jawwāl. The second article tries to present The Academies of Arabic Language institution in solving this problem by providing two alternative methods of entering foreign languages into Arabic, namely derivation which is considered the most natural strategy and the Arabization strategy.

Several writings that concern in the case of taulĩd in certain fields are Balkis Amanilah Nurul Mivtakh (2019). This paper focuses her attention on the new vocabulary in Arabic in the field of technology which she specifically finds in the al-Akbar newspaper with the title Arabic Language Neologism on the Field of Technology in alAkhbār Newspaper ${ }^{21}$. As well as the writings of Raheem Challub Seber al-Kaabi (tt) who highlighted the entry of Arabic from English with the title Translating English Military Neologism into Arabic ${ }^{22}$.

\footnotetext{
${ }^{18}$ Al-Sayyid Muhammad Nașruddīn.

${ }^{19}$ Al-Sayyid Muhammad Nașruddīn.

${ }^{20}$ Cristina Solimando, 'Arabic neologisms in IT terminology: the role of the Academies', Bulletin d'études Orientales, 65.1 (April, 2017): 123-133.

${ }^{21}$ Balkis Aminallah Nurul Mivtakh, 'Arabic Neologism on the Field of Technology in al-Akhbār Newspaper', Izdihar: Journal of Arabic Language Teaching, Linguistics, and Literature, 2.1 (April, 2019): 17-34.

${ }^{22}$ Ramadan A. Elmgrab, Methods of Creating and Introducing New Terms in Arabic Contributions from English-Arabic Translation (Libya: University of Benghazi, 2011).
} 
It is no less important to look at some of the neological works taking place in the country. Musthofa, for example, a student of the Religion and Cross-Cultural Studies Program with an Interest in Middle Eastern Studies at the Gajah Mada University Graduate School in 2019, discussed Arabic vocabulary and terms that came from foreign languages, especially internet and computer languages with the title of the thesis Neology in Arabic: Morphological Studies, Syntax, and Semantics of Computer and Internet Terms in Modern Arabic. ${ }^{23}$ Likewise, the study of the use of foreign vocabulary in the Arabic dictionary was carried out by Asna Andriani, a postgraduate student of Arabic Language Study Program of Religion and Philosophy at UIN Sunan Kalijaga, with her thesis entitled Arabization of Foreign Vocabulary; Analysis of Phonology and Morphology on Absorption Vocabulary from English in the Al-Maurid Dictionary, ${ }^{24}$ and Study of social media language terms Facebook and WhatsApp written by Hanun Khiyaraotun Nisa in 2016 with the title Neologism in Arabic: Morphological and Semantic Study of Oprational Language Terms Social Media Facebook Version 68.0.0.37.59 and WhatsApp Version 2.12.556. ${ }^{25}$ Another research written by Aulia Nabila talked about the usage of foreign words in Arabic electronic advertisement: Website Extra. ${ }^{26}$

In the research above, generally, most of the case is about word production that comes from English in various fields. The interesting thing here is how the development of neological cases that occur from Indonesian. As happened in the case of production from English, the need to create new Arabic vocabulary was felt by Arabic language magazines or newspapers in Indonesia, which there is no equivalent meaning in Arabic sometimes.

One of the print media that contains the data on the development of Arabic language in Indonesia is Alo Indonesia magazine, which has been established since 1999. This magazine has an important position because it is an Arabic-language magazine in Indonesia that still exists today after many other magazines have been published, such as

${ }^{23}$ Musthofa, 'Neologi Dalam Bahasa Arab : Kajian Morfologis, Sintaksis Dan Sematik Terhadap Istilah Komputer Dan Internet Dalam Bahasa Arab Modern', Universitas Gadjah Mada (2009).

${ }^{24}$ Asna Andriani, 'Arabisasi Kosa-Kata Asing: Analisis Fonologi Dan Morfologi Pada Kosakata Serapan Dari Bahasa Inggris Dalam Kamus Al-Mawrid: Qamus `Araby-Inkiliziy’, UIN Sunan Kalijaga Yogyakarta (2010).

${ }^{25}$ Hanun Khiyarotun Nisa, 'Neologisme Dalam Bahasa Arab, Kajian Morfologis Dan Semantik Terhadap Istilah-Istilah Bahasa Oprasional Media Sosial Facebook Versi 68.0.0.37.59 dan WhatApp Versi 2.12.556', UIN Sunan Kalijaga Yogyakarta (2016). 
al-Wihdah, an-Nadwah, Lisān, Nādi magazines published by the State University of Malang, East Java and al-Badĩl magazine which has been published several times at Sunan Kalijaga Islamic University in Yogyakarta.

Alo Indonesia Magazine presents several columns such as tourism, culture, profiles, windows of middle east, education, innovation, research, economy, trade, investment, Indonesian workers, women, religion, health, flora and fauna, clothing, restaurants, shopping information and so on. This magazine presents new information in two directions, namely information about Indonesia for Arabs and at the same time providing information on the Arab world for Indonesians. The interesting thing in presenting news in a two-way manner is that this magazine presents a lot of new vocabulary and terms, especially those related to Indonesian discourse which of course will not be found in Arabic dictionaries. By making Alo Indonesia magazine as study material, especially the 2011-2017 edition with a sample of approximately 100 words and terms originating from Indonesian culture, researchers will focus their attention on two interesting things, namely how this magazine takes vocabulary and language terms. Arabic originating from Indonesian culture and what are the problems faced by the two media in carrying out this process.

\section{Method}

Type of the research is library research, the method used in this research is descriptive method ${ }^{27}$. The data search technique used is listening technique, by listening to the use of new Arabic words and terms in Alo Indonesia magazine, followed by taking notes on the data $\operatorname{card}^{28}$. The approaches used in this research are morphological and semantic approaches. Morphology is to play a role in describing the various forms of words based on the structure and changes that occur in the object of research. Changes in the form of words or containing one-word in other words in Arabic or by adding one or more letters will result in a change in meaning, so even the semantic approach cannot be ignored, namely an approach which concern to the nature of the meaning, both functional meaning, lexical as well as contextual meaning.

${ }^{26}$ Aulia Nabila, 'Penggunaan Kata Asing Dalam Iklan Elektronik Berbahasa Arab Di Website Exstra', UIN Sunan Kalijaga Yogyakarta (2017).

${ }_{27}^{27}$ Sudaryanto, Metode Linguistik (Yogyakarta: Gajah Mada University Pers, 1992), 62.

${ }^{28}$ M.S Mahsun, Metode Penelitian Bahasa, Tahapan Strategi, Metode dan Tehniknya (Jakarta: Rajawali Pers, 2007), 92. 
Some linguists suggest several ways in which foreign vocabulary is introduced into Arabic ${ }^{29}$. Ibrāhĩm Murād divided several types of neology and the variations. He divided neology into 5 kinds and 15 rules. Naşruddĩn, in his journal of the Faculty of Islamic and Arabic Studies, stated 7 (seven) patterns of neology formation. To read how Alo Indonesia Magazine captures new Arabic vocabulary from Indonesian discourse and culture, the writer will mention several rules specifically mentioning those put forward by Ibrahim Murad because his is considered to be more complete than others. Some of these rules are: Phonetic Neology (at-Taulĩd al-Şautĩy), which includes: a). Phoneme Replacement Neology $(I b d \bar{a} l)$; b). Theology of the exchange of phoneme positions (Qalb); c). Neology of Phonemes Similarities (Tamāţul); d). Neology of Tabayun (Tabāyun), and e). Intrusion Neology (Iqhām). Morphological Neology (al-Taulĩd alŞarfĩy) which includes: a). Derivative Neology (Isytiqāq); b). Coinase Neology (Nahtt); c). Composition of Neology (Tarkib); and d). Lexicalization of Neology (Mu'jamah). Semantic Neology (at-Taulĩd al-Dalāliy) which includes: a). Metaphorical Neology (Majāz); and b). Translational Neology (Tarjamah). Spontaneity Neology (at-Taulĩd bi al-Irtijāl) which includes: a). Absolute Spontaneous Neology (al-Irtijāl al-haqĩqiy); and b). Imitation Neology $(I t b \bar{a})$. Borrowing Neology (at-Taulĩd bil Iqțirāạ), which includes: a). Loan Neology (al-Dakhĩl), and b). Arabization Neology (al-Ta'rĩb) ${ }^{30}$.

\section{Result and Discussion}

The first time we read Alo Indonesia magazine, we will get so many names, both object names and regional names that this magazine introduces to readers. Based on these names, it can be observed that it only seems to imitate the sound of the original word or term which comes from Indonesian.

The absorption process carried out in this case can be categorized as at-Taulĩd bi al-Iqtirād by using a second method called Ad-Dakhĩl. This process is like transliterating vowels and consonants in Indonesian into Arabic. Look at the examples below:

\footnotetext{
${ }^{29}$ Murad, Muqaddimah Linazriyah Al- Mu'jam (Beirut, Dār al-Garb al-Islamī, 1997) 136-162.

${ }^{30}$ Murad.
} 
Table 1. Sound Imitation to Arabic Language

\begin{tabular}{|c|c|c|}
\hline No. & Words in Indonesia & Arabic Loanwords \\
\hline 1. & Kalimantan & كاليمنتن \\
\hline 2. & Samarinda & 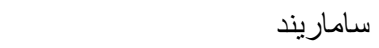 \\
\hline 3. & Jogjakarta & جكجاكرتا \\
\hline 4. & Mall & مول \\
\hline 5. & Indosat & 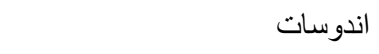 \\
\hline 6. & Telkomsel & تيلكوم سيل \\
\hline 7. & Taman Mini Indonesia Indah & تامن مينى اندونيسيا انداه \\
\hline
\end{tabular}

At first glance, this transliteration problem is quite simple, especially if there is not about the semantic aspect at all, but the problem is not as simple as imagined because not all vowels and consonants in Indonesian have their equivalent in Arabic. The author found the inconsistency of Alo Indonesia magazine to transliterate Arabic vocabulary from Indonesian, both vowels and consonants, as follows:

Table 2. Inconsistency in Vowels

\begin{tabular}{|c|c|c|c|c|}
\hline No. & $\begin{array}{l}\text { Vowel in } \\
\text { Indonesian }\end{array}$ & Vowel in Arabic & Examples in Indonesian & Examples in Arabic \\
\hline 1. & $\mathrm{~A}$ & أ & Amani Lubis & أماني لوبيس \\
\hline 2. & $\mathrm{E}$ & إ، إ+بي & Elisabet, Eka santi & إيكا سانتي، إليز ابيت \\
\hline 3. & I & إ، إبي & $\begin{array}{l}\text { Iskandar Muda, Ikan bakar } \\
\text { Cianjur }\end{array}$ & باكرتشيانجور \\
\hline 4. & $\mathrm{O}$ & أ+و & Ondel-ondel & أونديل أونديل \\
\hline 5. & $\mathrm{U}$ & أ+و & Agung Bandang & أوجونج باندانج \\
\hline 6. & $\mathrm{Ai}$ & أ+ي & Air Panas & اير باناس \\
\hline 7. & $\mathrm{Au}$ & g+_ & Merauke & ميروكي \\
\hline 8. & Oi & - & - & - \\
\hline
\end{tabular}

The sound of consonant is as follows:

Table 3. Inconsistency in Consonant

\begin{tabular}{|c|c|c|c|c|}
\hline No. & $\begin{array}{l}\text { Consonant in } \\
\text { Indonesian }\end{array}$ & $\begin{array}{l}\text { Consonant } \\
\text { in Arabic }\end{array}$ & $\begin{array}{l}\text { The consonant sound in } \\
\text { Indonesia }\end{array}$ & $\begin{array}{c}\text { The consonant sound in } \\
\text { Arabic }\end{array}$ \\
\hline 1. & B & ب & $\begin{array}{l}\text { Batak, } \\
\text { Becak,Betawi,Bukit, } \\
\text { Borobudur }\end{array}$ & بوروباك، بيتشاك، بتاوي، بوكيت \\
\hline
\end{tabular}




\begin{tabular}{|c|c|c|c|c|}
\hline 2. & $\mathrm{C}$ & 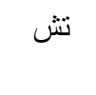 & $\begin{array}{l}\text { Cirebon, Campur Sari, } \\
\text { Canting }\end{array}$ & تشيربون، شامبور ساري ، شانتينج \\
\hline 3. & $\mathrm{D}$ & د & $\begin{array}{l}\text { Darma Bakti, } \\
\text { Denpasar,Dude Herlino, } \\
\text { Do dog Lojor }\end{array}$ & دوج دورج لَّي، دينباسر ، دودى هارلينو، \\
\hline 4. & $\mathrm{~F}$ & ف ف & $\begin{array}{l}\text { Fauzi Bowo, Fera, } \\
\text { Formula }\end{array}$ & فوزي بووو ، فير ا ، فورمولا \\
\hline 5. & G & ج & $\begin{array}{l}\text { Gaduda Food, Grogol,Gili } \\
\text { trawangan, Gunung Putri }\end{array}$ & جرارودا فود، جوروجول، جونيلي \\
\hline 6. & $\mathrm{H}$ & $\tau-\diamond$ & $\begin{array}{l}\text { Habibi Center, Heru } \\
\text { Susanto, Hegar manah }\end{array}$ & هيجارماناه سينتر ، هير سوسيتيو، \\
\hline 7. & $\mathbf{J}$ & 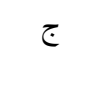 & $\begin{array}{l}\text { Jeumpa, Jalaksana, } \\
\text { Jerowacik }\end{array}$ & جومبا، جلاكسانا ، جيرو وتشيك \\
\hline 8. & $\mathrm{~K}$ & ك & $\begin{array}{l}\text { Kelapa Gading, Keraton, } \\
\text { Kuningan }\end{array}$ & كلابا جادينج ، كراتون ، كونينجان \\
\hline 9. & $\mathrm{~L}$ & J & Lamongan, Lebak, Luwak & لامونغان ، ليباك، لو اك \\
\hline 10. & M & 5 & $\begin{array}{l}\text { Madura,Mojokerto, Mega } \\
\text { Kuningan, Merauke }\end{array}$ & ميروكي مادورا، موجوكيرتو، ميجا كونينجان، \\
\hline 11. & $\mathrm{P}$ & ب & $\begin{array}{l}\text { Paramadina, Perak, } \\
\text { Pinang,Polonia, Pompong }\end{array}$ & بوموبنج \\
\hline 12. & Q & ق & $\begin{array}{l}\text { Komaruddin Hidayat, } \\
\text { Queensland }\end{array}$ & قمر الدين هدايت، كوينز لاند \\
\hline 13. & $\mathrm{R}$ & J & $\begin{array}{l}\text { Rambut, Rindu alam, Riau, } \\
\text { Rencong }\end{array}$ & رامبوت، ريندو عالم، رياو ، رينشونج \\
\hline 14. & $\mathrm{~S}$ & س & Senayan. Sinabung, studio & سينايان، سينابونج، الإستوديو ، ستوديو \\
\hline 15. & $\mathrm{~T}$ & $ت$ & $\begin{array}{l}\text { Toba, Tuanku,Tetabuhan, } \\
\text { Teluk Bayur }\end{array}$ & توبا، تو انكو ، تيتابوحان، تلوك بايور \\
\hline 16. & $\mathrm{~V}$ & ف ف & Video, Vitamin & الفيديو ، فيتامين \\
\hline 17. & $\mathrm{~W}$ & 9 & Wisata hati, Wayang & ويستا هاتي، و ايانج \\
\hline 18. & $\mathrm{X}$ & 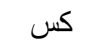 & Toxidemi & توكسيديمي \\
\hline 19. & $\mathrm{Y}$ & ي & $\begin{array}{l}\text { Yogyakarta, Yusuf } \\
\text { mansur, Yoyo Yusri }\end{array}$ & يوجياكرتا، جوكجاكرتا، يوسسف يويو يسرى \\
\hline 20. & $\mathrm{Z}$ & j & Zulkifli Hasan, Zamrud & ذو الكفل حسن، زمرد \\
\hline 21. & NG & ن & Agung, Bandung & أجونج، باندونغ \\
\hline 22. & NY & - & - & - \\
\hline
\end{tabular}

From the two tables above, the authors see that there are inconsistencies made by Alo Indonesia in transliterating both vowels and consonants. Vowels /e/ and /i/ are 
sounded with the letters $/ ! l$ and $/ \mathrm{L} /$, as is the case with the vowels $/ \mathrm{u} /$ and $/ \mathrm{o} /$ which are sounded with the letters / / / and /g The impact of this will make it difficult for Arab tourists who will pronounce the word /Elisabet/ or the word /Iskandar/ which may be pronounced in reverse to /Ĩlisabet/ or /Eskandar/. Likewise, what happened to the vowel $/ \mathrm{u} /$ and $/ \mathrm{o} /$ which both sounded in the transliteration with the letters $/ / /$ and $/ g /$, which also allowed errors in pronouncing the word /bukit/ with the sound of the word /Borobudur/ which was also pronounced /Bokĩt/ and /Būrūbūdūr/.

Moreover, with the inconsistency in translating consonants, consonants $/ \mathrm{b} /$ and $/ \mathrm{p} /$ are translated with one letter, namely /ب/. Consonants /c/, for example, are sometimes translated as consonants $/ /$ and $/ ش /$ or only. Likewise, the consonant /h/ is sometimes translated as consonant/ / / or / / If the Ministry of Education and Culture and the Ministry of Religion ever made a joint decision regarding the Arab-Indonesian transliteration in 2003 , then it is time for parties to try to do the opposite, while also showing that the Indonesian nation is capable of being a 'produsen' in the development of Arabic not always 'konsumen'.

In addition to the terms above, there are other terms that are formed in the tarki $b$ wasfĩ and tarkīb iḍafi or even combine the two. In this case - even what Alo Indonesia has taken the most is by the way of at-Taulĩd bi al-Tarjamah al-Harfiyyah, namely atTaulĩd which occurs from Indonesian to Arabic by means of moving al-madlul (the meaning) Indonesian into Arabic without being followed by ad-Dāl (the symbol), for example:

Table 4. Neology in the Form of Tarkīb Washfi

\begin{tabular}{|c|c|c|}
\hline No. & Words in Indonesian & Words in Arabic \\
\hline 1. & Orgen Tunggal & الأرغن المنفرد \\
\hline 2. & Hewan Langka & الحيو انات النادرة \\
\hline 3. & $\begin{array}{l}\text { Hewan-hewan terancam punah dan } \\
\text { dilindungi hukum }\end{array}$ & الحيو انات المهددة بالإنقر اض و المحمية بالقانون \\
\hline 4. & Jalan tol & الطريق السارع \\
\hline 5. & Jalur antar kota antar propinsi & الطرق ذات المسافة القريبة و المتوسطة و البعيدة \\
\hline 6. & Becak (Sepeda dengan 3 roda) & الدرجة ذات العجلات الثلابة \\
\hline 7. & Kamar dagang & الغرفة التجارية \\
\hline 8. & Negri plural & البلاد التعددية البلة \\
\hline
\end{tabular}


The translation of some of the terms above follows the tarkĩb was fi pattern where the first word is maușüf (subject that has adjective) and the second word is sifat (adjective), which is what Muṣthafa al-Gulāyain̄̄ as a word that comes after isim which functions to explain the state of $i \operatorname{sim}$ or to explain the state of something related to that $\operatorname{isim}^{31}$.

The word al-Munfarid (singular) is a characteristic of the word al-Organ, an electronic musical instrument equipped with tone blades ${ }^{32}$. Organ Tunggal is a musical performance on stage that does not require a number of other musical instruments and enough music is produced by electronic strings ${ }^{33}$. The words al-Nâdirah (rare), alMuhadadah (threatened) al-Muhammiyyah (protected) are the characteristics of the previous words, namely al-hayawānāt (animals) whose stinging population is small throughout world, which is less than 10 thousand heads ${ }^{34}$. The adjective used in the preceding phrase uses Isim Fäil and Isim Maf'ūl, including the fourth phrase which is characterized by the word $a s-S a \bar{r} r$ ' (fast) ${ }^{35}$. But for the translation of the phrase 'Jalan Tol' it becomes at-Tâariq as-Sāri will be similar with Indonesian because in Indonesian portrayals, 'Jalan Tol' are often equated with expressways without mentioning the meaning of 'Toll' at all which means roads paid ${ }^{36}$.

Unlike the four examples above, the adjective in the next two phrases is the word $z \bar{a} t$ which means șāhibah (The owner). Al-Gulāyainī explained that the words that should be characteristic in Arabic are isim al-fä'il and Isim musyabbah bi ism al-fäil, but in fact several other words can also be used including the word $z \bar{a} t .^{37}$ Thus, the two phrases above mean 'a road that has a short, medium and long distances' or are often called Jalur Antar Kota Antar Provinsi (AKAP) which means inter-city and inter-provincial routes, are clearly mentioned by Alo Indonesia magazine and the second phrase means 'bicycle which has three wheels' which we are known as Becak.

\footnotetext{
${ }^{31}$ Muşţafā al-Gulāyainĩ, Jamĩ' ad-Durūs al-Arabiyyah, Jūz III (Bairut: Mansyurat al-Maktabah al'Aşriyyah, 1990), 221-222.

${ }^{32}$ Tim Prima Pena, Kamus Besar Bahasa Indonesia (Gita Media Press, n.d.), 564.

${ }^{33}$ https://id.wikipedia.org/wiki/Organ_tunggal. Accessed on 6th of March, 2016 at 00.30 PM.

${ }^{34} \mathrm{http}: / / \mathrm{www}$. evo-rare.com/2015/02/hewan-dan-tumbuhan-langka.html. Accessed on 6th of March, 2016 at $00.30 \mathrm{PM}$.

${ }^{35}$ Muşţafā al-Gulāyainĩ, Jamĩ' ad-Durūs al-Arabiyyah, Jūz III, (Bairut: Mansyurat al-Maktabah al'Aşriyyah, 1990), 222.

${ }^{36}$ https://id.wikipedia.org./wiki.jalan_tol, Accessed on $6^{\text {th }}$ of March, 2016 at 00.30 PM.

37 Al-Gulayaini, Jami' al-Durus al-Arabiyyah, Juz III (Beirut Mansyurat al Maktabah al'Asriyyah,1990), 222-223.
} 
In contrast to the translation of the previous phrases, the last two phrases use adjectives from the form of a noun to an adjective or what is called in theory as al-taulid al-şarfĩy, then the word at-tijärah (trade (as noun) ) as a word objects are formed into attijāriyyah (trade but in adjective way), with the addition of the letter ya an-Nisbah, as well as the word at-ta'addud (plural) as a noun becomes at-ta'addudiyyah (plural (in adjective way)) with the same pattern.

Next, look at the literal translation process carried out with tarkíb iḍaffí, the examples are as follows:

Table 5. Neology in the Form of idāafah

\begin{tabular}{|c|c|c|}
\hline No. & Words in Indonesian & Words in Arabic \\
\hline 1. & Sabuk Pengaman & حز ام الأمان \\
\hline 2. & Ruang serbaguna & قاعة متعددة الأغر اض \\
\hline 3. & Karapan sapi & سباق البقر \\
\hline 4. & Taman Remaja Surabaya & حديقة الشباب سور ابايا \\
\hline 5. & Mafia Pajak & 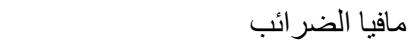 \\
\hline 6. & Ikatan Cedekiawan Muslim Indonesia & جمعية المثقفين المسلمين الإندونيسيين \\
\hline 7. & Angkutan dalam kota & نقل داخل المدينة \\
\hline
\end{tabular}

Al-tarkỉb al-id̄âfi is the result of adding two words containing the meaning hurūf $a l-j \bar{a} r$, which contains the letter al-Lām which means 'having' for the type of al-idâfah allämiyyah, contains the letter min which means 'from' or 'part of' for the type al-idâfah albayāniyyah, shows the meaning of ' $f \bar{\imath}$ ', which means 'in', for the type al-idâfah azzarfiyyah, implies the meaning of al-Käf li at-Tașbĩh, or shows the similarity ${ }^{38}$.

Based on al-tarkîb al-id̄âfi above, there seems to be no problem so that we can understand the phrase hizām al-Amāni means a belt for security, the phrase $q \bar{a}$ 'ah almutaaddidat al-agrād means 'Ruang Serbaguna' (Function room), it has the similar meaning with the phrase dār al-munāsābàt. Then sequentially sibāq al-baqar, hadīqah syabāb Surabaya, mafia aḍ-ḍaāib, and Jam'iyyah al-Musiaqqafín al-Muslimĩn wa alIndunisiyyin means the competition for cows, parks owned by Surabaya youths, mafia for taxes and associations of Indonesian Muslim intellectuals and finally the phrase naql dākhil al madīnah which means transportation in the city.

\footnotetext{
${ }^{38}$ Al-Gulayaini.
} 
More than that, Alo Indonesia presents many Indonesian expressions or what is often called at-ta'bir al-isțilāhi. According to al-Khuli, at-ta'bir al-isțilāhi is a word construction whose overall meaning differs from the meaning of each element ${ }^{39}$. According to Kridalaksana, it's a word construction if it is not the same as the combined meaning of its members ${ }^{40}$. Look at the following examples:

Table 6. Neology in the Form of at-Ta'bir al-Istilahi

\begin{tabular}{|c|c|c|}
\hline No. & Words in Indonesian & Words in Arabic \\
\hline 1. & (hidup) dari nol & من الصفر \\
\hline 2. & $\begin{array}{l}\text { Tidak punya apa-apa, segalanya, punya } \\
\text { segalanya }\end{array}$ & 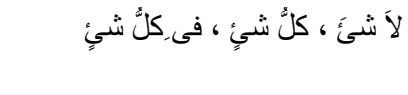 \\
\hline 3. & Tidak melihat sebelah mata & عدم النظر بعين واحد \\
\hline 4. & Gunung Es & جبل التلج \\
\hline 5. & Duri dalam daging & الثوكة فى جسم الأمة \\
\hline 6. & sapi panas, sapi dingin & البقر الساخن، البقر البارد \\
\hline 7. & Islam KTP & الإسلام على البطاقة \\
\hline
\end{tabular}

Based on the word structure of some of the examples above, actually there is no big difference from the structure in the previous examples. The structure of $J \bar{a} r$ and Majrūr, Muḍ̄âf and Muḍ̄ Ilaih are used, even al-Jumlah al-Ismiyyah structure is also used.

Based on at-Ta'bir al-Iștilāhī made by Alo Indonesia, as listed above, this magazine produces the meanings by at-Taulĩd al-Dalāliy and majāz (metaphorical) way or giving new meanings in the old vocabulary. Thus, the new meaning differs from the previous meaning either in the form of meaning expansion or vice versa as long as there is alāqah (linkage) between both of them.

The first term in the table reads min aṣ-ṣifr taken from Alo Indonesia magazine which tells the life story of Habibi and Ainun "dari nol (from zero/from scratch)" ${ }^{41}$. The smallest number in the calculation is nol (zero) and that is the original meaning, however the meaning of the symbol "nol (zero)" has been given a new meaning, especially if it is related to life. So, the zero point in this life means the simplest situation experienced by married couples who just started getting married. The point of equality between the old

${ }^{39}$ Muhammad Ali Al-Khuli, A Dictionary of Theoretical Linguistics: English-Arabic with An Arabic-English Glossary. (Beirut: Libraire Du Liban, 1982), 125.

${ }^{40}$ Harimurti Kridalaksana, Kamus Linguistik (Jakarta: Gramedia, 1983), 62.

41 Alo Indonesia (Jakarta : Yayasan Alo Indonesia, 2011), 40. 
meaning and the new meaning is that the expression "nol (zero)" is "the beginning of departure" for everything.

The second phrase which reads la syaia, kullu syai', and fi kullu syai also appeared when Alo Indonesia described the phases of the lives of Habibi and Ainun ${ }^{42}$. The original meaning of this expression is 'tidak ada segala sesuatu' (nothing), 'setiap sesuatu' (every single thing), and 'pada setiap sesuatu' (in every single thing). Based on the context of the journey of Habibi and Ainun, the expression above means 'berawal dari tidak punya apa-apa' (starting from having nothing), then gradually becoming 'segalanya' (everything), and 'mempunyai segalanya atau apapun' (having everything or whatever). The relationship between the old meaning and the new meaning of the first expression is the side of 'nothingness', the second and the third expression is the side of 'universality'.

The third phrase which reads 'adam an-nazru biain wāhid ${ }^{43}$ means not only based on one point of view, but when we look at the context that accompanies the discussion about Indonesian workers abroad, especially in Arab countries with all their struggles to countries in reducing poverty, becoming heroes of foreign exchange and also struggling for their families, this expression can mean 'not underestimating' and not diminishing their role in life.

The three expressions min aṣ-șifr and la syaia, kullu syai, and fì kullu syai, 'adam an-nazru biain wähid get their equivalents in Arabic, namely the Arab community has at least used this kind of thinking in their phrases. The expression min aș-ṣifr, for example, has an equivalent of this expression 'an-nājihūna badaū min aș-șifrr ${ }^{44}$, which means 'successful people are those who start from scratch'. The expression of kullu syai is found in many novels and short stories, for example in a collection of short stories by Taufiq alHakim, there is the sentence 'Kānat hazihi az-zaujah kullu syai li hayātihi wa kāna huwa kullu syai li hayātiha ${ }^{45,}$ which means 'it is said that the wife is everything for her husband's life and vice versa, her husband is everything for her life'. It is easy to find the equivalent word in an-naz̧ru biain wähid which means 'mocking' by browsing the internet which reads 'an-nās ya'isyūna biainain șahihain lākin lā yubșirūn illā biain

\footnotetext{
${ }^{42}$ Alo Indonesia (Jakarta : Yayasan Alo Indonesia, 2011), 40.

43 Alo Indonesia (Jakarta : Yayasan Alo Indonesia, 2011), 31.

${ }^{44}$ www.youtube.com?v=6GJLPI Abk. Downloaded on 6th of March, 2016 at 04.00 PM.

${ }^{45}$ Taufiq al-Hakim, Lailah az-Zafäf (Cairo: Maktabah Msr, t.t) 71.
} 
wahid $^{46}$, which means 'many people live with two normal eyes, but don't they see with one eye'.

The next two expressions Jabal as-salj and literally means asy-syaukah fi jism alummah 'gunung salju' (snow mountain) and 'duri dalam daging' (thorn in the flesh). These two expressions appear in discussions about the existence of Shia in Indonesia ${ }^{47}$. Apart from Alo Indonesia's attitude towards the existence of Shia people, these two expressions can mean 'bom waktu' (time bomb) and 'penyakit' (disease) or a 'barrier' for Muslims.

The next two expressions of al-baqar as-sākhin and al-baqar al-bārid appear in the context of the discussion about races of cows in Madura ${ }^{48}$. The expression al-Isläm 'ala al-bițāqah appeared in discussions about Indonesia's pluralistic nerves. Interpreting the above expression as 'Sapi panas' (hot cow) or 'Sapi dingin' (cold cow) or 'Islam di atas $K T P^{\prime}$ (the person who is considered a Muslim but only based on his/her identity card) is certainly not correct. For Arabs, it is difficult to understand expressions like this without knowing the context of Indonesian culture, and it is also difficult to translate these thoughts into the synonyms that are already in the minds of Arabs. In the context of Karapan sapi, 'Sapi panas' (hot cow) is a cow that is very easy to have a battle or running competition, while 'sapi dingin' (cold cow) is a cow that only wants to have a battle or running competition if it is triggered with food or being repeatedly whipped. Then, the phrase "Islam KTP" is very familiar to us, which is an expression that describes the Islam of some Muslims who have not carried out Islamic teachings properly.

In the context of translating the typical Indonesian expressions above, it could be wrong because sometime if the ideas and understanding of Indonesians that are transferred into ideas and understanding of Arabs are failed. But in contributing to the development of Arabic, Alo Indonesia has succeeded in introducing Indonesian culture to Arabs, as has the entry of the phrase 'Jalan kaki' (walking) in some Saudi Arabian societies even though they do not understand where the phrase came from and how to write it in their language. Anis Furaihah argues that the existence of 'Amiyah is viewed differently by linguists, some as a 'destroyer' of language and 'development of language' which is difficult to avoid, then these expressions need to be promoted, so that Arabs

\footnotetext{
${ }^{46}$ www.youtube/libyauno i/pos. Downloaded on 6th of May, 2016 at 04.00 PM.

47 Alo Indonesia (Jakarta : Yayasan Alo Indonesia, 2011), 71.

48 Alo Indonesia (Jakarta : Yayasan Alo Indonesia, 2011), 10-11.
} 
understand and even use the language in their daily conversations and use Western expressions and ideas.

\section{Conclusion}

From this discussion, the author concludes that Alo Indonesia magazine has taken the initiative to introduce Indonesian culture through Arabic by including words, phrases and even sentences that are characterized by Indonesia and entered in Arabic by means of at-Taulĩd al-Dalāliy and at-Taulĩd bi al-Iqtịāạ. Then, the biggest problem faced by the two media in the transliteration process from Indonesian letters into Arabic, considering that not all vowels and consonants in Indonesian are also present in Arabic. Likewise, it is difficult to find the equivalent of the idea of an expression in these two languages. The steps taken by the two media are right by presenting some Indonesian words and expressions that encourage Arabs to understand and even use them in their conversations. The researcher provides recommendations for the next study that is accordance with this discussion.

\section{Acknowledgment}

Researchers would like to thank all of the people who have contributed in completing this article. I also especially thank the editor for delivering this article. May Allah give the strength to all of us to develop Arabic. Finally, it can be useful and contributing to develop a better life.

\section{References}

Abderrahman, Wajih Hamad, 'A Linguistic Study of The Impact of English On Arabic Word-Formation', Islamic Studies, 34.2 (2016): 223-231

Abu Zalāl 'Isamuddin Abd as-Salam, at-Taabīr al-Iștilāhiyyah baina an-Nazriyyah wa at-Taṭbīq, Kairo: al-Ajyāl, 2007.

Alo Indonesia, Yayasan Alo Indonesia (Jakarta, 2011)

Amīn, Ahmad, Fajr al Islām, Beirūt: Dār al-Kutub,1975

Andriani, Asna, 'Arabisasi Kosa-Kata Asing: Analisis Fonologi Dan Morfologi Pada Kosakata Serapan Dari Bahasa Inggris Dalam Kamus Al-Mawrid: Qamus 'ArabyInkiliziy’ (UIN Sunan Kalijaga Yogyakarta, 2010) 
Chaer, Abdul dan Leonie. "Sosiolinguistik Perkenalan Awal," 30. Jakarta: PT Rineka Cipta, 2014

Daud, Muhammad Muhammad, Mu’jam at-Ta'bìr al-Istilāhī fi al 'Arabiyyah alMu'āsirah, Kairo, Dār al-Garĩb, 2003

Didaoi, Mohammed, Translator as Terminologists (Vienna: Lecture Delivered at the second Seminar on Translation Theory and Alications, 1996)

Al-Dzubyani, Abdul Rahman. "an-Nājihūna Badaū min aṣ-Sifr." Youtube. Accessed March $6^{\text {th }}, 2016$. https://www.youtube.com/watch?v=6GJLPIAhAbk

Elmgrab, R. A., Methods of Creating and Introducing New Terms in Arabic Contributions from English-Arabic Translation. Libya, University of Benghazi, 2011.

Evo Rare. "Hewan dan Tumbuhan Langka." Evo Rare. Accessed March 6th, 2016. http://www.evo-rare.com/2015/02/hewan-dan-tumbuhan-langka.html.

Ghembaza, M. I. E. K., Smai, A. H., \& Aloufi, K. S. Arabic Solid-Stems for an Efficient Morphological Analysis. Arabian Journal for Science and Engineering, 2018, 43(12): 7373-7383.

Ghonīm, Kamal Ahmad, Āliyāt at-Ta'rib wa Shinaah al-Mushtholahat al-Jadidah, Falestine, Wizarat ta'līm al-Āli al-Falisthinī 2014

Al-Gulāyainĩ, Muşţafā. Jamĩ' ad-Durūs al-Arabiyyah, Juz III, Bairut: Mansyurat alMaktabah al- 'Aşriyyah, 1990.

Hafiz, Albara altahera, Lexical Borowwing (ta'rib) in Arabic Computing Tecnology :Isuses and Strategies, Durham Theses, Durham University, 2015. http://ethesis.dur.ac.uk/11195/

Al-Hakim, Taufiq. Lailah az-Zafäf. Cairo: Maktabah Msr, t.t

Al-Hamd, Muhammad ibn Ibrahim, Fiqh al-Lugah, Mafhūmuh, Mauḍ̄'ātuh, Qadayāh, Riyad, Dār ibn Khuzaimah, 2005

Hunwick, John O, 'West Africa and The Arabic Language', Sudanic Africa, 15.2004 (2018): 133-44.

Imāmuddin Basyuni, Kamus Arab-Indonesia, Pola Aktif, Depok, Ulinuha Press, 2003

İsā Ahamad, Kitab at-Tahdīb fì Ușūl at-Ta'rīb, Kairo, Dār al-Afāq al-Arabiyyah, 2001

Al- Kaabi, Raheem Cholloub Seber, Translating English Military Neologism in Arabic, Iraq, Departement of Translation College of Art al-Mustansiriyh Univesity, t.t

Khalīl, Hilmy. Al-Muwalladu: Dirāsatun fĩ Numuwwin wa Tatawwur al-Lugah Al'Arabiyyah Ba'dal-Islām. Cairo: al-Haiah al-Mișriyyah al-'Āmah Lil-Kitāb, 1978. 
Al-Khūli, Muhammad Ali, Dictionary of Theoretical Linguistic,Beirut: Librairie du Liban, 1982

Kmail, Rahma Abd al-Rahma Naji, The Translatability of English Social Media Neologisms into Arabic The Translatability of English Social Media Neologisms into Arabic, Palestine, Faculty of Graduate Studies an-Najah National University, 2016

Kridalaksana . Harimurti, Kamus Linguistik Jakarta: Gramedia Press, 1992.

M. Badawi, Al-Muhĩt, Oxford Studi Dictionary English-Arabic (Beirut: Daral-Kutub alIlmiyyah, 2004)

Al-Magriby, Abdul Qādir bin Mușțafa. Al-Isytiqāq wat-Ta'rīb. Cairo: Lajnah at-Ta'līf wat-Tarjamah wan-Nasyr. 1947

Mahsun, MS, Metode Penelitian Bahasa, Tahapan Strategi, Metode, dan tekniknya, Jakarta, Rajawali Pers, 2007.

Al-Markaz al-Filistiny li al-I'lam. "An-Nadzru bi 'Ayn Wahidah!!!". al-Markaz alFilistiny li al-I'lam. Accessed May $6^{\text {th }}, \quad 2016$.

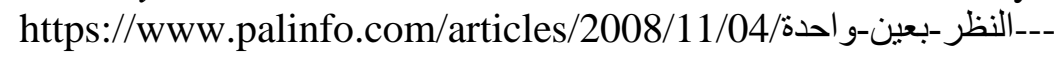

Mivtakh, Balkis Aminullah, 'Arabic Language Neologism on the Field of Technology in al-Akhbār Newspaper', Izdihār : Journal of Arabic Language Teaching, Linguistics, and Literature, 1 (2019): 17-34.

Murad, Ibrāhīm Ibn, Muqaddimah li Nazariyyah al-Mu'jam. Tūnis: Dār al-Garĩb alIslāmy, 1997.

Musthofa, 'Neologi Dalam Bahasa Arab: Kajian Morfologis, Sintaksis Dan Sematik Terhadap Istilah Komputer Dan Internet Dalam Bahasa Arab Modern', Universitas Gadjah Mada (2009)

Nabila, Aulia, 'Penggunaan Kata Asing Dalam Iklan Elektronik Berbahasa Arab Di Website Exstra', UIN Sunan Kalijaga Yogyakarta (2017)

Nașruddīn, as-Sayyid Muhammad, 'Al-Muwallad Fil-'Arabiyyah Baina Ar-Raf̣ WalQabül', Ed. 2. Vol. 3. (Egypt, 2017): 138-264.

Nisa, Hanun Khiyarotun, 'Neologisme Dalam Bahasa Arab, Kajian Morfologis Dan Semantik Terhadap Istilah-Istilah Bahasa Oprasional Media Sosial Facebook Versi 68.0.0.37.59 Dan WhatApp Versi 2.12.556', UIN Sunan Kalijaga Yogyakarta (2016)

Qan̄̄̄ Hāmid Sādiq, al-Ma'ājim wa al-Mustalahāt, Mabāhis fì al Mușțalahāt wa al Ma'ājim wa at-Ta'rīb, Saudi Aabiya, ad-Dār as-Su'ūdiyah, 2000.

Al-Qulaishi, Abdullah ibn Ahmad Muhammad, at Taulĩd al-Lughawi inda al-Qadhi at Tünijī, Mamlakah al-Arabiyyahas-Suudiyyah Wizārah at-Ta' līm al-Ālī, 2008 
Solimando, C.. 'Arabic neologisms in IT terminology: the role of the Academies', Bulletin d'études Orientales, 65 (2017): 123-133.

Sudaryanto, Metode Linguistik, Ke arah memahami Metode Linguistik, Yogyakarta, Gajah Mada Universiti Press, 2000

Tim Prima Pena, Kamus Besar Bahasa Indonesia, Jakarta, Cita Media Press, t,t.

Al-Tūnijī, Muhammad, al-Mu'arrab wa ad-Dakhil fi al-Lugah al-Arabiyyah wa Adabihā. Baerut: Dār al-Ma'rifah, 2005.

Van Dam, Nikolaos, 'Arabic Loanwords in Indonesian Revisited', Bijdragen Tot de Taal-, Land- En Volkenkunde, 166.2/3 (2010): 218-43.

Versteegh, Kees, 'Linguistic Contacts between Arabic and Other Languages', Arabica, 48.4 (2001): 470-508.

Qutbuddin, Tahera, 'Arabic in India : A Survey and Classification of Its Uses, Compared with Persian', Journal of the American Oriental Society, 127.3 (2007): 315-38.

Hunwick, John O., 'West Africa and The Arabic Language', Sudanic Africa, 15.2004 (2018): 133-44.

Versteegh, Kees, 'Linguistic Contacts between Arabic and Other Languages', Arabica, 48.4 (2001): 470-508.

Wikipedia. "Organ Tunggal." Wikipedia. Accessed March 6th, 2016. https://id.wikipedia.org/wiki/Organ_tunggal.

Wikipedia. "Jalan Tol." Wikipedia. Accessed March $6^{\text {th }}, 2016$. https://id.wikipedia.org./wiki.jalan_tol.

Yajioui, Abdel Rahman, Developing Language and the Language Development in the Arab World, Arab Center for Research \& Policy Studies (2012). http://www.jstor.org/stable/resrep12652. 